\title{
An Economic Assessment for the Effect of Farm Location along the same Irrigation Canal on Crop Production in Dakahlia Governorate
}

\section{Enas Moh. Abbas Saleh Hammad Hosni Ahmed El Sayed \\ Agricultural Economics Research Institute (AERI), Agricultural Research Centre (ARC). 1. Introduction}

One of the greatest challenges facing humanity is how to use scarce water resources in an equitable and sustainable way (Allam, 2005). It has often been highlighted that irrigated agriculture receives the lion's share of water diversions, and that there is a need to improve resource-use efficiency (FAO, 2012). On the other hand, economic implications of inequitable water distribution among farmers at the head-ends and tail-ends of tertiary canals have been addressed in several studies reporting that tail-enders usually receive small amounts of irrigation water and sometimes no water at all. The head-end farmers, however, receive a large share of canal water (Rao, 1987 and MWRI, 1998). Hence, head-end farms receive more water and tail-end farms generally suffer from scarcity of water thus, the head-reach farms can control the flow going to the tail-end portion of the command and the tailenders do not have any control over this process (Allam, 2002). Unequal distribution of water is a result of water overuse at the head-end of the canal bringing less water toward its ends. Moreover, farmers whose fields are furthest from the water sources frequently have least secure water supply, while the farmers whose fields are closer to water source receive an unduly large share of channel water (Santha et al, 2013). Other studies reported problems with unequal water delivery between farms located at the head-end of the canal and the tail-ends, causing inequity in water distribution between upstream and tail-end users. According to (FAO, 2005), there may be inequity between head-end and tail-end farms along same canal (especially long canals), although tail problems on canals are often simply a reflection of low water levels in the branch canal, meaning there is insufficient depth of flow at the head-end of the canal to convey the required discharge to the end. However, crops' yields in farms away from the water courses sharply declined across the irrigation outlet. These yields decline when moving from the head towards middle- and tail-end locations (Bhattarai et al, 2002). Another study by (Malashkhia, 2003) reported that tail-enders were experiencing the losses of the yield due to under-irrigation caused by unequal distribution of water.

Similarly, (Santha et al, 2013) identified an income gap between the upper and lower reaches of the canal, which is due to the large share of water used by farmers at the head-end of the canal to the detriment of those at the tail-end. The low cooperation levels and low communication facilities preventing the feedback of downstream farmers to upwards are another aspect of complicated issue. Farmers cannot always be blamed for their ignorance or low awareness since the overirrigation practices that lead to water shortages downstream often are induced by unreliability of the water provision in canals. Uncertainty in water availability pushes them to over-irrigate, as they are not sure in water delivery next time (Holmen, 1991).

Based on (Ghazouani et al, 2014) to cope with this situation, a certain number of typical adaptation strategies and practices commonly found in the literature were first confirmed, including changing cropping systems, crafting collective irrigation rules, reusing drainage water, practicing deficit and night irrigation, and overirrigating whenever water is available.

Such circumstances lead to several problems that may be attributed to a number of negative effects on the production of irrigated crops including delayed crop establishment, reduced crop development and yields as well as frequent crop failure. This, in combination with insufficient availability of and access to water 
resources at the canal level, has led to frustration and a loss of smallholders' farm income. Problems are largely created by the inconvenient rotation system and uncoordinated operation of individual pumps. A poor understanding of the irrigation requirements of their crops and the unreliability and insufficiency of the water supply has led farmers along same canals to pump as much as they can afford during daytime, despite the fact that water services to tail-end users may be unsatisfied (FAO, 2005).

These discussions raised an important research question on why do the main crops' yields and their efficiency of production, and water use efficiency along the same tertiary canal vary under similar agro-climatic, socio-economic and management conditions in Dakahlia Governorate. Consequently, the key hypothesis to be tested is that head, middle and tail-end farms located on the same canal gain the same yields of main crops at the same level of efficiency for crop production and same level of water use efficiency.

Accordingly, the objectives of this study are to analyse variations in the main crops' yields along the canal, factors contributing to such variations, impact of farm location on the economic efficiency of crop production, impact of location on water use efficiency for main crops, and impact of location on the average total revenues of main crop rotations prevailing in the study sample in the Governorate. The study attempts to reach some recommendations for decreasing such farm-level variations.

In order to reach these objectives, the study is divided into three further sections. In the second section the methodological framework is provided whereas, results and discussions are presented in the third section. The last section concludes with some remarks and recommendations on policy implications.

It is within this framework that the current study was carried as part of the activities of "Enhancing Food Security in Arab Countries Project (EFSAC-Egypt) Phase II" jointly implemented by the team of work from the Agricultural Research Centre of Egypt (ARC) and the International Centre for Agricultural Research in the Dry Areas (ICARDA).

\section{Methodological Framework}

\subsection{Data source and analysis}

Region of the study: The study was conducted in the old lands located at East Nile Delta of Lower Egypt, Dakahlia Governorate. According to (MALR, 2012, 2013 and 2014) records, the cultivated area of the Governorate reached about 611 thousand feddans as an average of the period (2011-2013) whereas, the average cropped area reached about 1.33 million feddans during the same period with a cropping intensity of about $217 \%$, indicating that the cultivated area is planted more than twice a year. Wheat, clover and sugar beet contribute to about $47.9 \%, 24.5 \%$, and $10.6 \%$, respectively of the cultivated area in winter season in the Governorate whilst in the summer season, rice, maize, and cotton area contributed to about $68.7 \%, 5.3 \%$, and $7.6 \%$, respectively of the cultivated area in the Governorate during the same period.

Surveying Procedure and Data Collection: Data was collected from a socioeconomic survey conducted in 2014/2015 in Dakahlia Governorate. A two stage sampling design was used in this study to make representative sample. The primary sampling unit was the canal selected on the basis of secondary data collected from the Irrigation Directorate. The stratification of farms was based on farm location along the canal (head, middle and tail reaches) and planting most crops prevailing in the Governorate, as well. Finally, a random sample of 140 farms was selected of which 41, 57 and 42 farms were located at the three reaches, respectively.

\subsection{Analytical methods}

Descriptive statistics such as percentage was used to analyse the socioeconomic characteristics of the farmers in the study area. The main indicators of 
economic efficiency of production and water use efficiency for the main field crops were calculated. Besides, a one-way between subjects Analysis Of Variance (ANOVA) was conducted to compare the effects of farm location along the same canal on the yields, total revenues, variable costs, gross margins, water productivity and gross margins per unit of water for the studied crops. Moreover, a mathematical model by means of dummy variable technique was developed and used to estimate the effect of location along head, middle and tail-reaches of the canal on the yields, total revenues and gross margins of the studied crops as well as the average total revenue for crop rotations prevailing in the study area. This model form was as given below:

$Y_{i}=a_{0}+a_{1} D_{h}+a_{2} D_{m}+U_{i}$ (equation 1) where:

$\mathrm{Y}_{\mathrm{i}}$ : yield (ton/feddan) or total revenue (LE/feddan) or gross margin (LE/feddan) or average total revenue for the crop rotation (LE/feddan);

$\mathrm{D}_{\mathrm{h}}$ : dummy variable for farms located at the head-reach of the canal $\left(\mathrm{D}_{t=1}\right.$ if the location is head, $\mathrm{D}_{\mathrm{t}}=0$ otherwise);

$\mathrm{D}_{\mathrm{m}}$ : dummy variable for farms located on the middle of the canal $\left(\mathrm{D}_{\mathrm{m}}=1\right.$ if the location is middle, $\mathrm{D}_{\mathrm{m}}=0$ otherwise); $\mathrm{a}_{0}$ : constant $=$ mean of $\mathrm{Y}$ for farms located at the tail-end of the canal;

i: denotes farm;

$a_{1}, a_{2}$ : coefficients to be estimated;

$\mathrm{U}$ : error term.

Data was also used to estimate the production functions. Separate analysis was undertaken for wheat, clover, sugar beet, rice, maize and cotton. The production function was specified using a range of variables including farm location, seeds, organic manure, chemical fertilizers, pesticides and labour, and estimated with a set of functional forms including linear, log-linear, log-log (Cobb-Douglas) and quadratic. The functional form that had the best fit for the given data set was finally estimated with a set of independent variables as given below:

$$
\begin{aligned}
& \operatorname{Ln} Y_{i}= b_{0}+a_{1} D_{h}+a_{2} D_{m}+b_{1} \operatorname{Ln}\left(X_{1 i}\right)+b_{2} \operatorname{Ln}\left(X_{2 i}\right)+b_{3} \operatorname{Ln}\left(X_{3 i}\right)+b_{4} \operatorname{Ln}\left(X_{4 i}\right)+b_{5} \operatorname{Ln}\left(X_{5 i}\right) \\
&+b_{6} \operatorname{Ln}\left(X_{6 i}\right)+U_{i} \ldots \ldots \ldots \ldots \ldots \ldots \ldots \ldots \ldots \ldots \ldots \ldots \ldots \ldots \ldots \ldots \ldots \ldots \ldots \\
&\text { equation } 2)
\end{aligned}
$$

\section{where:}

$\mathrm{Y}$ : the yields of wheat or clover or sugar beet or rice or maize or cotton (ton/feddan);

$\mathrm{D}_{\mathrm{h}}$ : dummy variable for farms located at the head-reach of the canal $\left(\mathrm{D}_{\mathrm{h}}=1\right.$ if the location is head, $\mathrm{D}_{\mathrm{t}}=0$ otherwise);

$\mathrm{D}_{\mathrm{m}}$ : dummy variable for farms located in the middle $\left(\mathrm{D}_{\mathrm{m}}=1\right.$ if the location is middle, $\mathrm{D}_{\mathrm{m}}=0$ otherwise);

$\mathrm{X}_{1}$ : quantity of seeds in $\mathrm{kg} /$ feddan; $\quad \mathrm{X}_{2}$ : quantity of organic manure in $\mathrm{m}^{3} /$ feddan;

$\mathrm{X}_{3}$ : quantity of nitrogenous fertilizers in $\mathrm{kg} /$ feddan; $\mathrm{X}_{4}$ : quantity of phosphorus fertilizers in $\mathrm{kg} /$ feddan;

$\mathrm{X}_{5}$ : cost of pesticides in LE/feddan (due to the diversity of forms and properties and disability to measure, the physical quantities of pesticides used); $\mathrm{X}_{6}$ : labour (man-day/feddan);

i: denotes farm;

\section{Results and Discussion}

\subsection{Characteristics of selected sample in the study area}

Farmer's age: About 7\%, 10.5\% and 5\% of head, middle and tail-enders were younger than 45 years old, respectively whereas, about $49 \%, 37 \%$ and $43 \%$ of them were within the age group of (45-55) years old in that order. The head, middle and tail-enders older than 55 years old represent $44 \%, 53 \%$ and $52 \%$, respectively (Table $1)$. The results showed that the tail-enders were relatively older since about $95 \%$ of them were of older than 45 years.

Farming experience: About 37\%, 30\% and 21\% of the head, middle and tailend farmers gained less than 20 years of farming experience, respectively whereas, about $41 \%, 44 \%$ and $36 \%$ of them got (20-30) years of experience in that order. The 
$\varepsilon r v \quad$ An Economic Assessment for the Effect of Farm Location along the

same Irrigation Canal on Crop Production in Dakahlia Governorate

head, middle and tail-enders who got more than 30 years of experience represent about $22 \%, 26 \%$ and $43 \%$, respectively. This result revealed that the tail-enders gained good farming experience as about $79 \%$ of them spent more than 20 years in farming activities (Table 1).

Level of education: Table 1 showed that respectively about 17\%, 10.5\% and $21 \%$ of the head, middle and tail-enders were Illiterates whereas, about $27 \%, 40 \%$ and $17 \%$ of them were high school graduates, respectively. Moreover, about $15 \%$, $9 \%$ and $12 \%$ of them were university graduates, respectively. Generally speaking, the tail-enders were low-educated, as compared to the head-end and middle farmers.

Table (1): Farmer's characteristics in the study sample.

\begin{tabular}{|c|c|c|c|c|c|c|c|c|}
\hline Farmer's & \multicolumn{2}{|c|}{ Head-reach } & \multicolumn{2}{|c|}{ Midddle } & \multicolumn{2}{c|}{ Tail-end } & \multicolumn{2}{c|}{ Overall } \\
\cline { 2 - 9 } Characteristics & Frequency & $\%$ & Frequency & $\%$ & Frequency & $\%$ & Frequency & $\%$ \\
\hline Age & $\mathbf{4 1}$ & $\mathbf{1 0 0}$ & $\mathbf{5 7}$ & $\mathbf{1 0 0}$ & $\mathbf{4 2}$ & $\mathbf{1 0 0}$ & $\mathbf{1 4 0}$ & $\mathbf{1 0 0}$ \\
< 45 years & 3 & 7.3 & 6 & 10.53 & 2 & 4.76 & 11 & 7.9 \\
45 - 55 years & 20 & 48.8 & 21 & 36.84 & 18 & 42.86 & 59 & 42.1 \\
> 55 years & 18 & 43.9 & 30 & 52.63 & 22 & 52.38 & $\mathbf{7 0}$ & 50.0 \\
\hline Farming Experience & $\mathbf{4 1}$ & $\mathbf{1 0 0}$ & $\mathbf{5 7}$ & $\mathbf{1 0 0}$ & $\mathbf{4 2}$ & $\mathbf{1 0 0}$ & $\mathbf{1 4 0}$ & $\mathbf{1 0 0}$ \\
< 20 years & 15 & 36.59 & 17 & 29.8 & 9 & 21.43 & 41 & 29.3 \\
20 - 30 years & 17 & 41.46 & 25 & 43.9 & 15 & 35.71 & 57 & 40.7 \\
> 30 years & 9 & 21.95 & 15 & 26.3 & 18 & 42.86 & 42 & 30.0 \\
\hline Level of Education & $\mathbf{4 1}$ & $\mathbf{1 0 0}$ & $\mathbf{5 7}$ & $\mathbf{1 0 0}$ & $\mathbf{4 2}$ & $\mathbf{1 0 0}$ & $\mathbf{1 4 0}$ & $\mathbf{1 0 0}$ \\
Illiterate & 7 & 17.1 & 6 & 10.5 & 9 & 21.4 & 22 & 15.7 \\
Can Read \& Write & 13 & 31.7 & 19 & 33.3 & 18 & 42.9 & 50 & 35.7 \\
Prim. \& Prep. School & 4 & 9.8 & 4 & 7.0 & 3 & 7.1 & 11 & 7.9 \\
High School & 11 & 26.8 & 23 & 40.4 & 7 & 16.7 & 41 & 29.3 \\
University Graduate & 6 & 14.6 & 5 & 8.8 & 5 & 11.9 & 16 & 11.4 \\
\hline
\end{tabular}

Source: The results of the survey 2014/2015.

Cropping pattern: Wheat occupied $68 \%, 56 \%$ and $50 \%$ of winter cultivated areas in head, middle and tail, respectively. Clover and sugar beet together respectively occupied about $21 \%, 38 \%$ and $50 \%$ of winter cultivated areas in the head, middle and tail-end farms (Table2). In the summer season, rice was dominant at the head and middle whereas, maize occupied 13\%,19\% and $14 \%$ of the areas in cultivated in the three locations, respectively. Besides, cotton covered $7 \%, 4 \%$ and $54 \%$ of summer cultivated areas in this order. It is worth mentioning that most of tailenders were more reliant on crops which required comparatively less water and on cash crops.

Table (2): The cropping pattern in the study sample.

\begin{tabular}{|c|c|c|c|c|c|c|c|c|}
\hline \multirow[b]{2}{*}{ Crops } & \multicolumn{2}{|c|}{ Head-reach } & \multicolumn{2}{|l|}{ Middle } & \multicolumn{2}{|c|}{ Tail-end } & \multicolumn{2}{|c|}{ Overall } \\
\hline & $\begin{array}{c}\text { Area } \\
\text { (feddan) }\end{array}$ & $\%$ & Area (feddan) & $\%$ & $\begin{array}{c}\text { Area } \\
\text { (feddan) }\end{array}$ & $\%$ & $\begin{array}{c}\text { Area } \\
\text { (feddan) }\end{array}$ & $\%$ \\
\hline Winter Crops & 89.5 & 100 & 181.63 & 100 & 135.13 & 100 & 406.26 & 100 \\
\hline W & 61.25 & 68.44 & 10 & 56.39 & 67 & & 230.67 & 56.78 \\
\hline & 10.33 & 11.54 & 33.5 & 18.44 & 23.13 & 17.12 & 66.96 & 16.4 \\
\hline Suga & 8.5 & 9.50 & 36 & 19.82 & 44 & 32.56 & 88.5 & 21.78 \\
\hline On & 4.5 & 5.03 & 3 & 1.65 & 0 & 0.00 & 7.5 & 1.85 \\
\hline $\mathrm{Pe}$ & 4 & 4.47 & 0.5 & 0.28 & 0 & 0.00 & 4.5 & 1.11 \\
\hline $\mathrm{F}$ & 0 & 0.00 & 3.42 & 1.88 & 0 & 0.00 & 3.42 & 0.84 \\
\hline Winter & 0.92 & 1.03 & 2.79 & 1.54 & 1 & 0.74 & 4.71 & 1.16 \\
\hline Summer & 87.29 & 100 & 183.56 & 100 & 135.41 & 100 & 406.26 & 100 \\
\hline & 67.75 & 77.61 & 134.13 & 73.07 & 41.55 & 30.69 & 243.43 & 59.92 \\
\hline Ma & 11.33 & 12.98 & 35.51 & 19.35 & 19.36 & 14.30 & 66.19667 & 16.2 \\
\hline & 6.25 & 7.16 & 7 & 3.81 & 73.5 & 54.28 & 86.75 & 21.3 \\
\hline $\begin{array}{l}\text { Summer } \\
\text { vegetables }\end{array}$ & 1.96 & 2.25 & 6.92 & 3.77 & 1 & 0.74 & 9.88 & 2.43 \\
\hline Fruii & & $\mathbf{0}$ & 2 & $\mathbf{1 0 0}$ & 2.75 & 100 & $\begin{array}{l}4.75 \\
475\end{array}$ & 100 \\
\hline Cropped Area & 176.79 & & 367.19 & & 273.29 & & 817.27 & \\
\hline
\end{tabular}

Source: The results of the survey 2014/2015.

Crop rotations: The main crop rotations prevailing in the study area are wheat + rice, wheat + maize, clover + rice, clover + maize, sugar beet + cotton, and sugar beet + maize. 
Irrigation system, type of canal and water flow: The results showed that all head, middle and tail-end farms used flood irrigation and the selected canal is a traditional open earthen tertiary canal (non-improved) and all the sample farms have their irrigation water delivered on an irrigation rotation basis at a scheme of 4 days on and 6 days off. This maintains to eliminate the variation among the sample farms in terms of irrigation condition.

Source of irrigation: Fresh water is the main source of irrigation in the target site, contributing to about $85 \%, 83 \%$ and $65 \%$ of irrigation water used in the head, middle and tail-ends, respectively (Table 3 ). In addition, groundwater and mixed water are used to cover water shortage occurring during summer months. Groundwater contributes to $2 \%, 7 \%$ and $12 \%$ of water used in the said locations, respectively. Mixed water represents $13 \%, 10 \%$ and $12 \%$ of irrigation water in the three locations, respectively. Sometimes, both sources are used to irrigate the same crop at the same time. Moreover, drainage water is used in the tail-end as a supplementary source of water due to insufficient freshwater. These results are confirmed by (HLPE, 2015) and (Hoevenaars, 2004) reporting that tail-enders compensate water shortage by pumping from drains. This, in turn, increases their pumping costs, their land remains saline, and yield reduction due to water stress is more likely to occur.

Table (3): Source of irrigation in the study sample.

\begin{tabular}{|c|c|c|c|c|c|c|c|c|}
\hline \multirow{2}{*}{ Source of Irrigation } & \multicolumn{2}{|c|}{ Head-reach } & \multicolumn{2}{c|}{ Middle } & \multicolumn{2}{c|}{ Tail-end } & \multicolumn{2}{c|}{ Overall } \\
\cline { 2 - 9 } & Frequency & $\%$ & Frequency & $\%$ & Frequency & $\%$ & Frequency & $\%$ \\
\hline Fresh Water & 41 & 85 & 57 & 83 & 42 & 65 & 140 & 77 \\
\hline Groundwater & 1 & 2 & 5 & 7 & 8 & 12 & 14 & 8 \\
\hline Drainage Water & 0 & 0 & 0 & 0 & 7 & 11 & 7 & 4 \\
\hline Mixed Water & 6 & 13 & 7 & 10 & 8 & 12 & 21 & 12 \\
\hline Total & $\mathbf{4 8}$ & $\mathbf{1 0 0}$ & $\mathbf{6 9}$ & $\mathbf{1 0 0}$ & $\mathbf{6 5}$ & $\mathbf{1 0 0}$ & $\mathbf{1 8 2}$ & $\mathbf{1 0 0}$ \\
\hline
\end{tabular}

Source: The results of the survey 2014/2015.

Irrigation water sufficiency and equity: Table 4 revealed that about $66 \%$ of the interviewed farmers believed that irrigation water available in the canal was insufficient to irrigate their crops. Besides, about $37 \%, 67 \%$ and $93 \%$ of the head, middle and tail-enders believed in this, respectively.

Table (4): Responds of farmers about irrigation water sufficiency and equity in the study sample.

\begin{tabular}{|c|c|c|c|c|c|c|c|c|}
\hline & \multicolumn{2}{|c|}{ Head-reach } & \multicolumn{2}{|c|}{ Middle } & \multicolumn{2}{|c|}{ Tail-end } & \multicolumn{2}{|c|}{ Overall } \\
\hline & Freq.* & & Freq.** ${ }^{*}$ & $\%$ & Freq.* ${ }^{*}$ & $\%$ & Freq.** ${ }^{*}$ & $\%$ \\
\hline Water sufficiency & 41 & 100 & 57 & 100 & 42 & 100 & 140 & 100 \\
\hline Sufficient & 26 & 63.4 & 19 & 33.3 & 3 & 7.1 & 48 & 34.3 \\
\hline Insufficient & 15 & 36.6 & 38 & 66.7 & 39 & 92.9 & 92 & 65.7 \\
\hline Reasons behind water insufficiency & 15 & 100 & 38 & 100 & 39 & 100 & 92 & 100 \\
\hline High water level at the head-reach & 2 & 13.3 & 16 & 42.1 & 26 & 66.7 & 44 & 47.8 \\
\hline Inadequate water-rotation-flow & 7 & 46.7 & 19 & 50.0 & 9 & 23.0 & 35 & 38.0 \\
\hline $\begin{array}{l}\text { Short distance between the head-reach } \\
\text { and the distributary canal }\end{array}$ & 6 & 40.0 & 3 & 7.9 & 4 & 10.3 & 13 & 14.2 \\
\hline $\begin{array}{l}\text { Farmers' practices to cope with water } \\
\text { insufficiency }\end{array}$ & 35 & 100 & 75 & 100 & 112 & 100 & 222 & 100 \\
\hline Practice night irrigation & 6 & 17.1 & 12 & 16.0 & 18 & 16.1 & 36 & 16.2 \\
\hline Use drainage water & 0 & 0.0 & 7 & 9.3 & 15 & 13.4 & 22 & 9.9 \\
\hline Use groundwater & 1 & 2.9 & 11 & 14.7 & 17 & 15.2 & 29 & 13.0 \\
\hline Use raised-bed & 7 & 20.0 & 14 & 18.7 & 9 & 8.0 & 30 & 13.5 \\
\hline Ask to increase wet days & 10 & 28.6 & 19 & 25.3 & 12 & 10.7 & 41 & 18.5 \\
\hline Follow crop rotations & 4 & 11.4 & 5 & 6.7 & 11 & 9.8 & 20 & 9.0 \\
\hline Add manure & 2 & 5.7 & 4 & 5.3 & 13 & 11.6 & 19 & 8.6 \\
\hline Use drought-tolerant varieties & 5 & 14.3 & 2 & 2.7 & 7 & 6.3 & 14 & 6.3 \\
\hline Clean the Mesqa & 0 & 0.0 & 1 & 1.3 & 10 & 8.9 & 11 & 5.0 \\
\hline Water equity & 41 & 100 & 57 & 100 & 42 & 100 & 140 & 100 \\
\hline Equitable distribut & 9 & 22.0 & 51 & 89.5 & 40 & 95.2 & 100 & 71.4 \\
\hline Inequitable distribution & 32 & 78.0 & 6 & 10.5 & 2 & 4.8 & 40 & 28.6 \\
\hline
\end{tabular}

Note: * Freq. denotes frequency.

Source: The results of the survey 2014/2015. 
\& $q \quad$ An Economic Assessment for the Effect of Farm Location along the

same Irrigation Canal on Crop Production in Dakahlia Governorate

However, head farmers may over-irrigate during the on-period as a means of storing water in the soil profile. About $48 \%, 38 \%$ and $14 \%$ of the farmers respectively reported higher water level at the head-reach rather than at the tail-end, inadequate duration of water-rotation-flow, and shorter distance between the headreach and the distributary canal as compared to the distance between tail-end and the distributary canal, as the main reasons resulting in insufficiency of irrigation water. Moreover, $67 \%, 23 \%$ and $10 \%$ of tail-enders respectively the said reasons, as the main reasons behind insufficiency of irrigation water.

Water shortage usually occurs in summer due to increasing water consumption in summer, evaporation due to high temperature, and lack of water as the main reasons resulting in water shortage occurring in summer. Besides, middle and tailenders frequently faced water shortage times more than head-reach farms. In order to cope with water insufficiency, the farmers reported that they usually ask irrigation authorities to increase wet days $(18.5 \%)$ as well as practicing night irrigation (16\%), using raised-bed $(13.5 \%)$, using groundwater $(13 \%)$. Turning to tail-enders, only $16 \%, 15 \%$ and $13 \%$ reported carrying out night irrigation, using groundwater, using drainage water, and adding manure to improve soil fertility and water holding capacity as the main practices they follow to cope with water insufficiency.

Besides, about $71 \%$ of the farmers believed that fields furthest from the endreach frequently have least secure water supply while fields closer to the head receive an unduly large share of water supply, reflecting inequitable water distribution in favour of farmers at the head-reach. Furthermore, farmers in the head-reach spoke about their good luck and recognized being in a favourable situation, tail-enders referred to injustice water sharing arrangements. This result was confirmed by (WMRI, 2010) reporting that the reduction of water supply at the head-reach decreased the amount of fresh water at the tail-end resulting in unequal water sharing.

3.2. Effect of farm location along the same canal on the economic efficiency of production and water use efficiency for main crops in the study area

The study crops were selected on a basis of the largest cultivated area by crops in winter and summer seasons. Therefore, wheat, clover and sugar beet were selected for winter season whereas, rice, maize, and cotton were selected for the summer season, since they represented about $95 \%$ and $98 \%$ of the total cultivated area in both seasons, respectively (Table 2). Other field crops were not selected due to small number of observations.

Wheat: Table 5 revealed that the yield of wheat grown at the head, middle, and tail-end respectively reached 3.41, 3.44 and 3.09 ton/feddan. Besides, the yield of wheat grown in the middle was the highest since wheat is low-medium sensitive to water shortages. This result is in line with (FAO, 2012) reporting that excess water (especially at the head-reach) can cause waterlogging and depress wheat growth and yield substantially whereas, water stress during grain filling leads to shrivelled wheat grains. The variable costs of wheat were the highest in the middle whereas, they were the lowest at the tail-reach since the tail-enders used less fertilizers as compared to other famers who tend to use more chemical fertilizers to compensate nutrient leaching with excess water supply. This result was confirmed by (Reddy et al, 2013) reporting that over-irrigation, especially at the head-reach may lead to nutrient leaching. The total revenues of wheat grown at the head, middle, and tail-end reached LE 10.65, 10.74 and 9.69 thousand per feddan, respectively whereas, the gross margins of wheat grown at the three farm locations reached LE 7.37, 7.46 and 6.82 thousand per feddan in that order. Water productivity (WP) for wheat was the highest in the middle $\left(1.836 \mathrm{Kg} / \mathrm{m}^{3}\right)$. This is confirmed by the fact that the best environment for crop production is achieved when the plants' root zones are kept adequately moist 
without using excessive water (El Gamal, 2000) achieved in middle farms. The gross margin per unit of water for wheat grown at the middle was the highest (LE 3978 per thousand $\mathrm{m}^{3}$ ). ANOVA results showed statistical significant effect of farm location on all of these variables for wheat grown in the three locations.

Table (5): Indicators of economic efficiency and water use efficiency in the study sample.

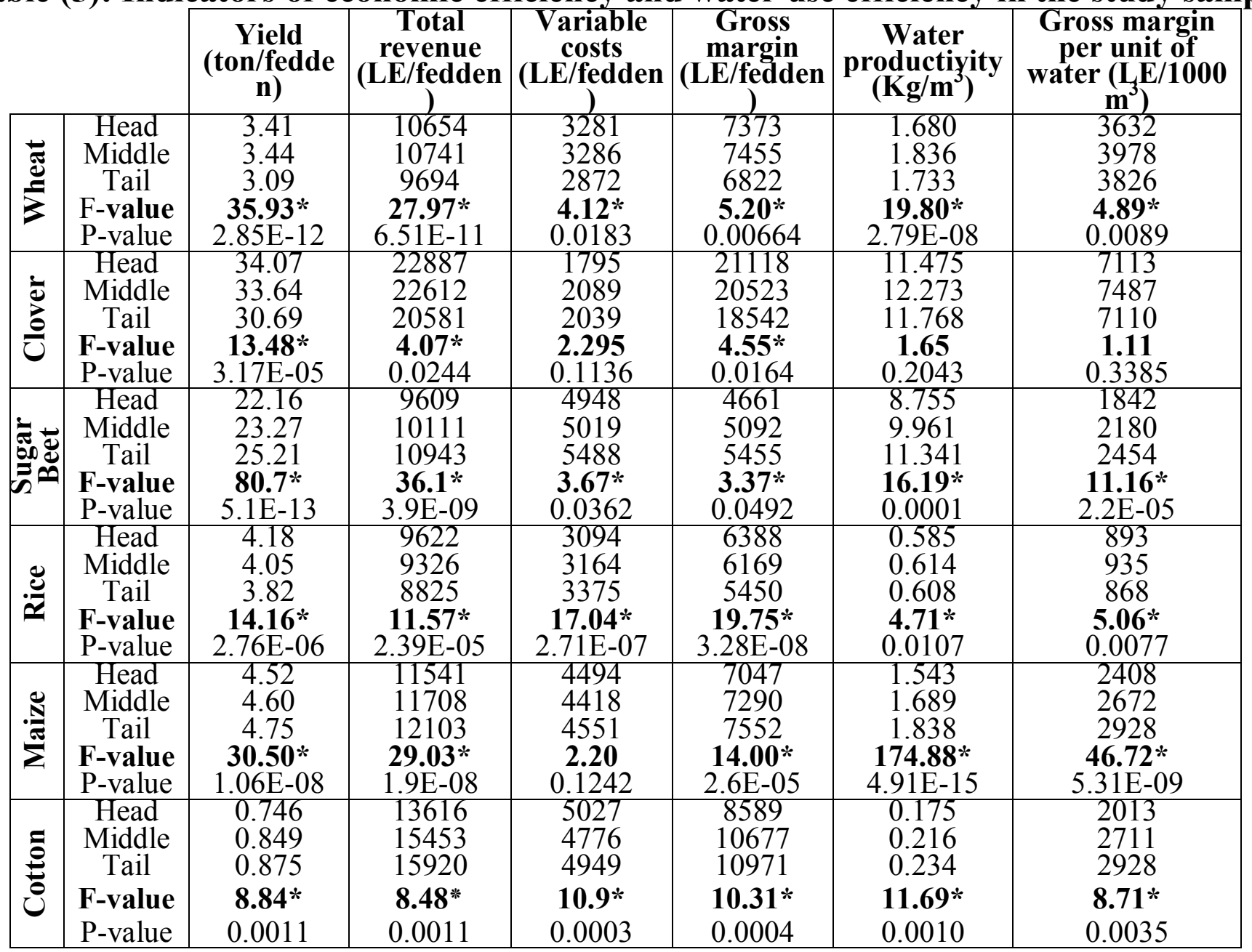

Note: $(*)$ indicates statistical significant difference at the $5 \%$ level.

Source: The results of the socio-economic farm and household survey 2014/2015.

On the other hand, Table 6 illustrating the results of the developed mathematical model (equation 1) revealed a statistical significant increase of the yield for wheat grown in farms located at the head-reach and in the middle respectively estimated at about 0.33 and 0.35 ton/feddan over that obtained in farms located at the tail-end.

Accordingly, the effect of the middle location on the yield of wheat is greater than that of the head-reach farm location. Besides, the variation of location explains about $33 \%$ of the variation in the yields of wheat grown in the three locations along the canal. In addition, there is a statistical significant increase of the total revenue for wheat grown in farms located at the head-reach and in the middle respectively estimated at about LE 0.96 and 1.05 thousand per feddan over that obtained in farms located at the tail-end. Besides, the variation of location explains about $28 \%$ of the variation in the total revenues of wheat grown in the three locations. Moreover, there is a statistical significant increase of the gross margin for wheat grown in farms located at the head-reach and in the middle respectively estimated at about LE 0.55 and 0.63 thousand per feddan over that obtained in farms located at the tail-end. Besides, the variation of location explains about $10 \%$ of the variation in the gross margins of wheat grown in the three locations. 
$\left\{\Psi_{1} \quad\right.$ An Economic Assessment for the Effect of Farm Location along the same Irrigation Canal on Crop Production in Dakahlia Governorate

Table (6): The results of the mathematical model for main crops in the study sample. \begin{tabular}{|l|l|l|l} 
Yield (ton/feddan) & Total Revenue (LE/feddan) & Gross margin (LE/feddan)
\end{tabular}

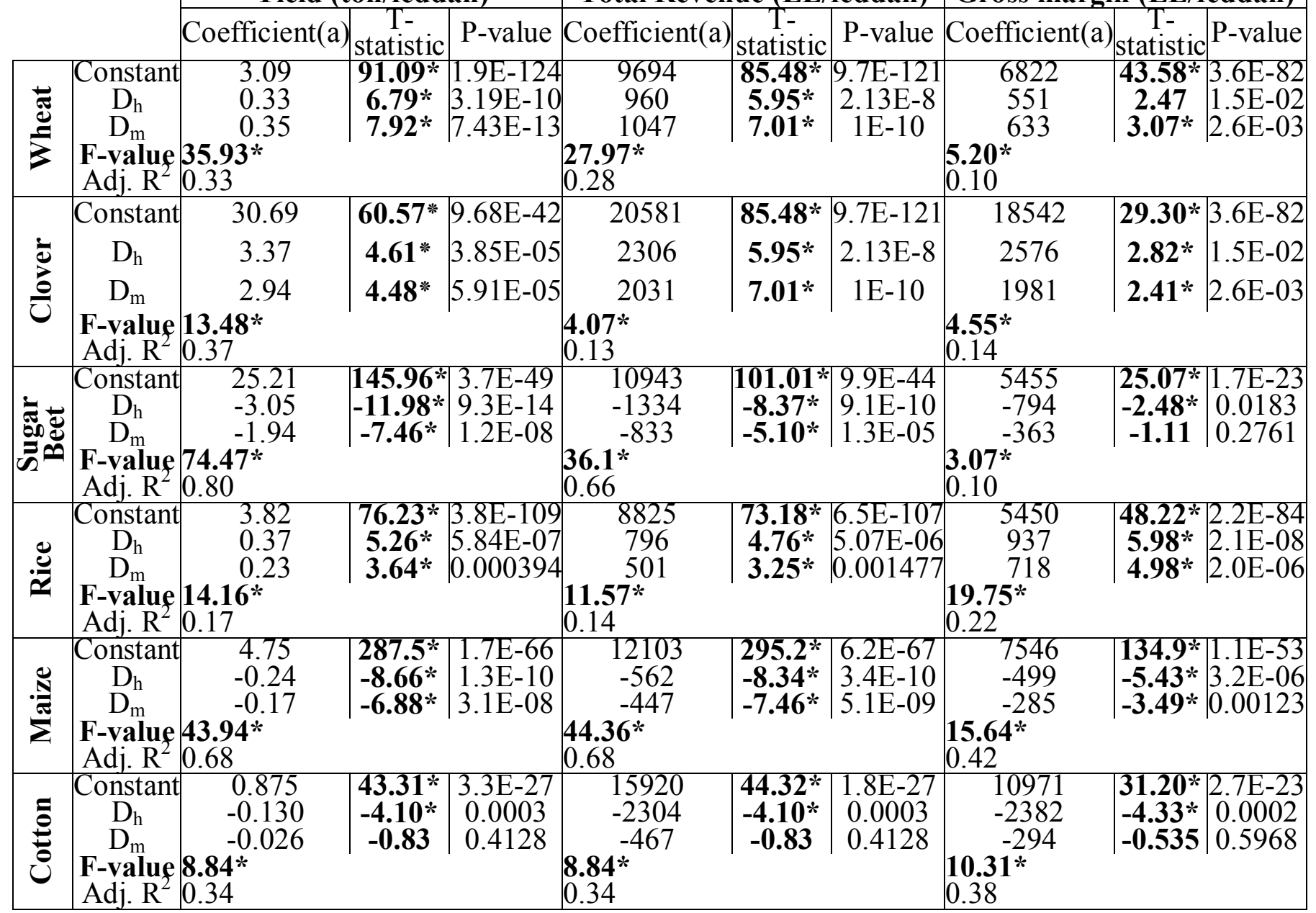

Note: $(*)$ indicates statistical significant difference at the $5 \%$ level.

Source: The results of the socio-economic farm and household survey 2014/2015.

Clover: Based on Table 5, the yield of clover grown at the head was higher (34.07 ton/feddan) and it decreases towards the tail of the canal (30.69 ton/feddan) since clover is a water-intensive crop. In addition, the variable costs of clover were the highest in the middle of the canal. The variable costs were the highest at the tail since tail-enders used more seeds as compared to head and middle famers. Therefore, the total revenues and gross margins decreased towards tail-enders. The WP and gross margin per unit of water for clover were the highest in the middle, reaching $12.27 \mathrm{Kg} / \mathrm{m}^{3}$ and LE 7487 per thousand $\mathrm{m}^{3}$, respectively. The results showed significant differences in the yields, total revenues and gross margins of clover grown among the three locations, indicating significant effect of location on these variables among the locations. Besides, the results of the mathematical model (Table 6) showed significant increase of the yield for clover grown at the head and in the middle of the canal respectively reached 3.37 and 2.94 ton/feddan over that obtained in farms located at the tail. The variation of location explains $37 \%$ of the variation in the yields of clover grown in the three locations.

There is significant increase of the total revenue for clover grown at the head and in the middle respectively of LE 2.31 and 2.03 thousand per feddan over that obtained by tail-enders. The variation of location explains $13 \%$ of the variation in the total revenues in the three locations. Moreover, there is a statistical significant increase of the gross margin for clover grown in farms located at the head and in the middle respectively estimated at LE 2.58 and 1.98 thousand per feddan over that obtained by tail-enders. Therefore, the effect of the head location on the gross margin of clover is greater than that of the middle location. The variation of location explains 
about $14 \%$ of the variation in the gross margins of clover grown in the three locations.

Sugar beet: The yield of sugar beet grown at the tail-end was the highest, reaching 25.21 ton/feddan (Table 5) since sugar beet is low-medium sensitive to water shortages (FAO, 1989) whereas, it was the lowest at the head-reach (22.16 ton/feddan). This result was confirmed by (Reddy et al, 2013) reporting that overirrigation, especially at the head of the canal may lead to nutrient leaching, water table increases, or runoff and erosion on slightly slopping lands. Moreover, based on (FAO, 2012), over-irrigation near harvest reduces root sucrose concentration of sugar beet and increases processing costs. It is worth mentioning that farmer's skills and experience play a good role in this regard since tail-enders gained good farming experience, enabling them to make use of water available for irrigating their crops. Besides, the variable costs of sugar beet were the highest at the tail whereas, they were the lowest at the head since farmers located at the later used less chemical fertilizers, pesticides and hired labour as compared to other famers. The total revenue and gross margin of sugar beet grown at the tail-end was the highest, reaching LE 10.94 and 5.46 thousand per feddan in that order. The total revenues and gross margins of sugar beet increased towards the tail since the yields of sugar beet increased towards the tail, as well. The WP and gross margin per unit of water for sugar beet grown at the tail were the highest, reached $11.341 \mathrm{Kg} / \mathrm{m}^{3}$ and $\mathrm{LE} 12454$ per thousand $\mathrm{m}^{3}$ in that order. ANOVA results showed statistical significant differences in these variables, indicating significant effect of location on all of these variables for sugar beet grown in the three farm locations. The results of the developed mathematical model illustrated in Table 6 showed a statistical significant decrease of the yield for sugar beet grown at the head and in the middle respectively estimated at about 3.05 and 1.94 ton/feddan below that obtained at the tail. Besides, the variation of location explains about $80 \%$ of the variation in the yields of sugar beet grown in the three locations along the canal. Besides, there is a statistical significant decrease of the total revenue for sugar beet grown at the head and in the middle respectively estimated at about LE 1.33 and 0.83 thousand per feddan below that obtained by the tail-enders. In addition, the variation of location explains about $66 \%$ of the variation in the total revenues of sugar beet grown in the three locations. Moreover, there is a statistical insignificant decrease of the gross margin for sugar beet grown at the head and in the middle respectively estimated at about LE 0.79 and 0.36 thousand per feddan below that obtained at the tail. The variation of location explains $10 \%$ of the variation in the gross margins of sugar beet grown in the three locations along the canal.

Rice: Based on the results illustrated in Table 5, the yield of rice grown at the head-reach was higher and it decreases towards the tail-reach since rice is a heavy water-consuming crop. The yield of rice grown at the head, middle, and tail-end respectively reached $4.18,4.05$ and 3.82 ton/feddan. This is caused by unequal water allocation among the reaches, inefficiency of irrigation water distribution, the high consumptive use for rice as one of the extremely sensitive crops to water shortage (FAO, 2012). The variable costs of rice were the highest at the tail since the tailenders used more seeds, fertilizers, pesticides and hired labour as compared to head and middle famers. The total revenue and gross margin of rice grown at the head were the highest, reaching LE 9.62 and 6.39 thousand per feddan in that order since as stressed earlier, the variable costs were higher for the tail-enders. The WP for rice grown in the middle and at the tail were the highest respectively reaching 0.614 and $0.608 \mathrm{Kg} / \mathrm{m}^{3}$. Besides, the gross margin per unit of water for rice grown in the middle was the highest. ANOVA results showed significant differences in these variables, 
\& rr An Economic Assessment for the Effect of Farm Location along the same Irrigation Canal on Crop Production in Dakahlia Governorate

indicating significant effect of location on all of them for rice grown in these locations. Furthermore, Table 6 illustrating the results of the mathematical model showed a statistical significant increase of the yield for rice grown at the head-reach and in the middle of the canal respectively estimated at 0.37 and 0.23 ton/feddan over that obtained at the tail-end. The variation of location explains $17 \%$ of the variation in the yields of rice grown in these locations.

Moreover, there is a statistical significant increase of the total revenue for rice grown at the head-reach and in the middle respectively estimated at LE 0.80 and 0.50 thousand per feddan over that obtained at the tail-end. The variation of location explains $14 \%$ of the variation in the total revenues of rice grown in these locations. Besides, there is a statistical significant increase of the gross margin for rice grown at the head-reach and in the middle respectively estimated at LE 0.94 and 0.72 thousand per feddan over that obtained at the tail-end. Moreover, the variation of location explains $22 \%$ of the variation in the gross margins of rice grown in the three locations along the canal.

Maize: Table 5 revealed that the yield of maize grown at the head, middle, and tail-end of the canal respectively reached about 4.52, 4.60 and 4.75 ton/feddan. Besides, the yield of maize grown in the tail-end of the canal was the highest since maize is medium-high sensitive to water shortages (FAO, 1989) whereas, it was the lowest at the head. This result is in line with (FAO, 2012) reporting that excess water (especially at the head) can cause waterlogging and can depress maize growth and yield substantially and it is confirmed by (Reddy et al, 2013) reporting that overirrigation, especially at the head, may lead to nutrient leaching, water table increases, or runoff and erosion on slightly slopping lands as aforementioned. In addition, farmers in the tail-enders gained good farming experience therefore, they combined some practices to mitigate the effects of water shortage on yields. The variable costs of maize were the highest at the tail-end. However, the variable costs of maize were the lowest in the middle since the middle famers used less seeds, chemical fertilizers and hired labour as compared to head and tail-enders. Moreover, the total revenue and gross margin of maize grown at the tail-end were the highest. Besides, WP for maize grown at the tail-end was the highest since irrigation water is abundantly available and over-used by the head farmers thus, increasing water consumption at the head location. The gross margins per unit of water for maize grown at the tail-end was the highest. Excluding the variable costs, ANOVA results showed statistical significant differences in these variables, indicating significant effect of location on all of these variables (except for the variable costs) for maize grown in the three farm locations. Based on the mathematical model (Table 6), there is a statistical significant decrease of the yield for maize grown at the head and middle respectively reaching 0.24 and 0.17 ton/feddan below that obtained at the tail. Besides, the variation of location explains $68 \%$ of the variation in the yields in the three locations. There is a significant decrease of the total revenue for maize grown at the head and middle respectively estimated at LE 0.56 and 0.45 thousand per feddan below that obtained at the tail-end. Moreover, the variation of location explains about $68 \%$ of the variation in the total revenues of maize grown in the three locations. Additionally, the results of the model revealed a statistical significant decrease of the gross margin of maize grown at the head and in the middle respectively estimated at LE 0.50 and 0.29 thousand per feddan below that obtained at the tail-end. Besides, the variation of location explains about $38 \%$ of the variation in the gross margins of maize grown in the three locations.

Cotton: The results of Table 5 revealed that the yield of cotton grown at the head, middle, and tail-end of the canal respectively reached $0.75,0.85$ and 0.88 ton/feddan. 
Besides, the yield of cotton grown at the tail-reach was the highest since cotton is low sensitive to water shortages (FAO, 1989) whereas, the yield of cotton was the lowest at the head-reach. This is largely attributed to that head farmers usually practice over irrigation due to lack of confidence in water supply, reducing the yield owing to the fact that excess water may cause nutrient deficiencies or crop diseases. Additionally, as aforementioned, tail-enders gained good farming experience enabled them to make use of water available for irrigating their crops. The variable costs of cotton were the highest at the head-reach whereas, they were the lowest in the middle since middle famers used less seeds and chemical fertilizers as compared to head and tail-enders. The total revenues and gross margins of cotton increased towards the tail-end. This result was in line with (El Gamal, 2000) reporting that poor irrigation management may waste labour and energy required for lifting excess water to the fields and from the drains. Accordingly, WP and gross margin per unit of water for cotton grown at the tail-end were the highest. ANOVA results showed statistical significant differences in these variables, indicating significant effect of location on all of these variables for cotton grown in these farm locations. The results of the model (Table 6) showed significant decrease of the yield for cotton grown at the head-reach of the canal estimated at 0.13 ton/feddan below that obtained by tail-enders whereas, there is a statistical insignificant decrease of the total revenue for cotton grown at the headreach estimated at LE 2.30 thousand per feddan below that obtained at the tail-end.

The variation of location explains $34 \%$ of the variation in both of the yields and total revenues of cotton grown in these locations. There is a statistical insignificant decrease of the gross margin for cotton grown at the head-reach estimated at LE 3.38 thousand per feddan below that obtained for tail-enders. Moreover, the variation of location explains about $38 \%$ of the variation in the gross margins of cotton in the three locations.

\subsection{Effect of farm location along the same canal on the production functions for main crops in the study area}

The production function estimates the effects of various factors of production on crops' yields. Separate analysis was undertaken for wheat, clover, sugar beet, rice, maize and cotton. Estimated coefficients measure absolute change in crops' yields per unit change in one factor, holding the others constant. Farm-location dummies capture the influence of location-specific factors other than those included in the production function. The results of the estimated equations are presented in Table 7.

Wheat production function: The estimation results of wheat production function are portrayed in Table 7 . The adjusted coefficient of determination (adj. $\mathrm{R}^{2}$ ) indicated that the studied factors of wheat production explain $94 \%$ of the variation in the wheat production. The T-statistic per estimator is given and the goodness of fit (reflected by the adj. $\mathrm{R}^{2}$ ), F-value, as well as the total number of observations are given in the final rows. The overall goodness of fit for this estimation concluded a sensible as well as a high degree of goodness of fit in adequately explaining the determinants of wheat output. Among the range of factors that could possibly affect wheat production, the location on the canal, seeds, manure, chemical nitrogenous fertilizers and labour during the entire growing season are found to be statically significant in the determination of wheat production. However, the signs of these coefficients indicate that all factors positively affect wheat production, except for the organic manure (with a negative coefficient) that negatively affects wheat production function. The primary reason for this negative sign is that farmers used larger amounts of manure than the recommended level. The F-value showed statically significance, implying that the independent variables significantly explained the variation in the dependent variable. Moreover, the coefficients of location dummies indicate that the yields of wheat grown in the head-reach and middle farms are higher than those at the tail-enders by about 0.18 and 0.13 ton/feddan in that order. 
sto An Economic Assessment for the Effect of Farm Location along the same Irrigation Canal on Crop Production in Dakahlia Governorate

Table (7): Estimates of the production functions (equation 2) for main crops in the study sample.

\begin{tabular}{|c|c|c|c|c|c|c|c|c|c|}
\hline & \multicolumn{3}{|c|}{ Wheat } & \multicolumn{3}{|c|}{ Clover } & \multicolumn{3}{|c|}{ Sugar Beet } \\
\hline & Coefficient & $\begin{array}{c}\text { T- } \\
\text { statistic }\end{array}$ & P-value & Coefficien & $\begin{array}{c}\text { T- } \\
\text { statistic }\end{array}$ & P-value & Coefficient & $\begin{array}{c}\text { T- } \\
\text { statistic }\end{array}$ & P-value \\
\hline Constant & -2.832 & $-17.3^{*}$ & $1.2 \mathrm{E}-35$ & 2.871 & $9.85 *$ & $7.0 \mathrm{E}-12$ & 2.162 & $2.87 *$ & $7.5 \mathrm{E}-03$ \\
\hline $\mathrm{D}_{\mathrm{h}}$ & 0.179 & $5.05 *$ & 1.4E-06 & 0.157 & $3.78 *$ & 5.5E-04 & -0.063 & $-4.86 *$ & $3.5 \mathrm{E}-\mathrm{C}$ \\
\hline $\mathrm{D}_{\mathrm{m}}$ & 0.129 & 4.41* & 2.2E-05 & 0.109 & 3.33* & 2.0E-03 & -0.037 & $-3.48 *$ & $1.6 \mathrm{E}-\mathrm{C}$ \\
\hline $\mathrm{X}_{1}(\mathrm{~kg} / \mathrm{fed})$. & 0.478 & $7.82 *$ & $1.6 \mathrm{E}-12$ & 0.001 & 0.02 & 0.98090 & 0.710 & $3.56 *$ & $1.1 \mathrm{E}-03$ \\
\hline $\mathrm{X}_{2}(\mathrm{~m} / \mathrm{fed})$. & -0.0 & $-2.66^{*}$ & 5.9E-03 & 0083 & $262 \%$ & & & & \\
\hline $\begin{array}{l}X_{3}(\mathrm{~kg} / \text { /ea. }) \\
X_{4}(\mathrm{~kg} / \text { fed. }\end{array}$ & $\begin{array}{l}0.281 \\
0.019\end{array}$ & 4.270 & $\begin{array}{l}3 . / \mathrm{E}-\mathrm{U} \\
0.36904\end{array}$ & $\begin{array}{r}-0.083 \\
0.064\end{array}$ & $-2.03 \%$ & $\begin{array}{l}8.1 \mathrm{E}-03 \\
9.1 \mathrm{E}-03\end{array}$ & $\begin{array}{c}-0.005 \\
0.084\end{array}$ & $2.38 *$ & $\begin{array}{l}0.813 \\
2.4 \mathrm{E}-\end{array}$ \\
\hline $\mathrm{X}_{5}$ (LE/fed.) & 0.001 & 0.13 & 0.89913 & & & & & & \\
\hline $\mathrm{X}_{6}$ (man- & 0.186 & $4.46 *$ & $1.7 \mathrm{E}-05$ & 0.145 & $2.40 *$ & $2.1 \mathrm{E}-02$ & 0.460 & $2.88 *$ & 7.3E-03 \\
\hline$\underset{n}{\text { Fdj. } R^{2}}$ & $\begin{array}{l}\mathbf{2 8 1} * \\
0.94 \\
140\end{array}$ & & & $\begin{array}{l}7.34 * \\
0.47 \\
44\end{array}$ & & & $\begin{array}{l}\mathbf{6 6 . 4 6 *} \\
0.86 \\
37\end{array}$ & & \\
\hline & & Rice & & & Maize & & & Cotton & \\
\hline Constant & 0.445 & 0.45 & $6.5 \mathrm{E}-01$ & 2.239 & $3.81 \%$ & $5.7 \mathrm{E}-04$ & -14.21 & -1.87 & 0.0732 \\
\hline $\mathrm{D}_{\mathrm{h}}$ & 0.105 & $4.45 *$ & $1.9 \mathrm{E}-05$ & -0.035 & $-2.19 *$ & $3.5 \mathrm{E}-02$ & -0.156 & $-3.96 \%$ & 0.000 \\
\hline $\mathrm{D}_{\mathrm{m}}$ & 0.073 & $3.82 *$ & $2.1 \mathrm{E}-04$ & -0.046 & $-3.56 \%$ & $1.1 \mathrm{E}-03$ & 0.006 & 0.12 & 0.9079 \\
\hline$X_{1}(\mathrm{~kg} /$ fed. $)$ & 0.092 & 1.03 & $3.0 \mathrm{E}-01$ & 0.174 & $7.55 \%$ & 3.3E-09 & 1.135 & 1.40 & 0.1720 \\
\hline $\mathrm{X}_{2}(\mathrm{~m} / \mathrm{fed})$. & & $272 *$ & $73 \mathrm{~F}_{-} 03$ & 0.437 & $4.37 *$ & $\begin{array}{l}8.5 \mathrm{E}-05 \\
2.6 \mathrm{E}-02\end{array}$ & ח 809 & $-266 \%$ & 00126 \\
\hline $\mathrm{X}_{4}(\mathrm{~kg} / \mathrm{fed})$. & 0.080 & $2.27 \%$ & $2.5 \mathrm{E}-02$ & $\begin{array}{l}0.042 \\
0.014\end{array}$ & 0.50 & $6.2 \mathrm{E}-01$ & & & 0.0120 \\
\hline $\mathrm{X}_{5}$ (LE/fed.) & & & & -0.021 & $-2.32 *$ & $2.6 \mathrm{E}-02$ & -0.321 & -1.83 & 0.0783 \\
\hline $\begin{array}{l}\mathrm{X}_{6} \text { (man- } \\
\text { day/fed.) }\end{array}$ & 0.121 & 0.90 & 3.7E-01 & 0.011 & 0.06 & 9.5E-01 & 2.848 & $2.35 *$ & 0.0265 \\
\hline F-value & $5.91 *$ & & & $12.62 \%$ & & & $3.14 *$ & & \\
\hline$\underset{n}{\operatorname{Adj} .} R^{2}$ & $\begin{array}{l}0.81 \\
132\end{array}$ & & & $\begin{array}{l}0.69 \\
42\end{array}$ & & & 0.30 & & \\
\hline
\end{tabular}

Notes: $Y$ denotes the yield; $D_{h}$ and $D_{m}$ denote dummy variables for farms respectively located at the head-reach and in the middle of the canal; $X_{1}, X_{2} ; X_{3}$, and $X_{4}$ respectively denote quantities of seeds, organic manure, nitrogenous fertilizers, phosphorus fertilizers; $X_{5}$ denotes cost of pesticides; $X_{6}$ denotes labour, and

$(*)$ indicates statistical significant difference at the $5 \%$ level.

Source: The results of the socio-economic farm and household survey 2014/2015.

Clover production function: The estimation of clover production function showed that the studied factors of clover production explain $47 \%$ of the variation in its production (Table 7). Besides, farm location, chemical fertilizers and labour are found to be statically significant in the determination of clover production. All these factors positively affect clover production, except for the nitrogenous fertilizers that negatively affect the production since farmers applied more than the recommended rates thus, reducing the nitrogen fixing ability of clover. The F-value of the estimated production function revealed that the independent variables significantly explained the variation in the dependent variable. The coefficients of location dummies indicate that the yields of sugar beet grown in the head-reach and middle farms are higher than those for tail-enders by about 0.06 and 0.04 ton/feddan, respectively.

Sugar beet production function: The of sugar beet production function shown in Table 7 revealed that the studied factors of sugar beet production explain $86 \%$ of the variation in the sugar beet production. Furthermore, farm location, seeds, chemical phosphorus fertilizers and labour are statically significant in determining sugar beet production. However, the three latter factors positively affect sugar beet production whereas, the location negatively affects sugar beet production since sugar beet is low-medium sensitive to water shortages. The F-value of the estimated production function showed that the independent variables significantly explained the variation in the dependent variable at that level. The coefficients of location dummies indicate that the yields of sugar beet grown in the head-reach and middle farms are lower than those at the tail-ends by about 0.06 and 0.04 ton/feddan in that order. 
Rice production function: The estimation for rice production function revealed that the studied factors of rice production explain $86 \%$ of the variation in the rice production (Table 7 ). Besides, the results revealed that farm location, chemical nitrogenous fertilizers and chemical phosphorus fertilizers are statically significant in the determination of rice production. However, location and chemical phosphorus fertilizers positively affect rice production whereas, the chemical nitrogenous fertilizers negatively affect rice production due to applying larger amounts of nitrogenous fertilizers over the recommended level. The F-value of the estimated production function was found to be significant. The coefficients of location dummies indicate that the yields of rice grown in the head-reach and middle farms are higher than those at the tail-end farms respectively by about 0.105 and 0.073 ton/feddan.

Maize production function: Table 7 illustrated the results of the estimation for maize production function indicating that the studied factors of maize production explain $69 \%$ of the variation in the maize production. Besides, the farm location, seeds, organic manure, chemical nitrogenous fertilizers and pesticides are statically significant in the determination of maize production.

However, all of these factors positively affect maize production, except for the location and pesticides that negatively affect maize production. The F-value of the estimated production function indicated that the independent variables significantly explained the variation in the dependent variable at that level. Moreover, the coefficients of location dummies indicate that the yields of maize grown in the headreach and middle farms are lower than those at the tail-end farms by about 0.035 and 0.046 ton/feddan, respectively.

Cotton production function: The results of the estimation for cotton production function indicating that the studied factors of cotton production explain $30 \%$ of the variation in the cotton production (Table 7 ). The head-reach farm location, chemical nitrogenous fertilizers and labour are statically significant in the determination of cotton production. However, labour positively affects cotton production whereas, the head-reach location and the chemical nitrogenous fertilizers negatively affect cotton production. The independent variables significantly explained the variation in the dependent variable at that level. The coefficients of location dummies indicate that the yields of cotton grown in the head and middle farms are lower than those at the tail by 0.16 and 0.90 ton/feddan, respectively.

\subsection{Effect of farm location along the same canal on the average total revenues} for the main crop rotations prevailing in the study area

Table 8 revealed that the wheat+rice rotation gained average total revenues estimated at about L.E. 20.28, 20.07 and 18.52 thousand, respectively at the head, middle and tail-end of the canal. The head-reach farmers gained the highest average total revenue for this crop rotation. Moreover, the head-reach farmers gained the highest average total revenue for wheat+maize, clover+rice and clover+maize rotations whereas, other crop rotations gained the highest average total revenue at the tail-end.

Table (8): Average total revenues for the main crop rotations in the study sample (000' LE/feddan).

\begin{tabular}{|c|c|c|c|c|c|}
\hline Crops & Head-reach & Middle & Tail-end & F-value & P-value \\
\hline Wheat+Rice & 20.28 & 20.07 & 18.52 & $37.26^{*}$ & $1.2 \mathrm{E}-13$ \\
\hline Wheat+Maize & 22.76 & 22.41 & 21.29 & $45.55^{*}$ & $6.8 \mathrm{E}-16$ \\
\hline Clover+Rice & 32.51 & 31.94 & 29.40 & $59.40^{*}$ & $2.7 \mathrm{E}-19$ \\
\hline Clover+Maize & 34.48 & 34.28 & 32.68 & $27.14^{*}$ & $1.2 \mathrm{E}-10$ \\
\hline Sugar Beet+Cotton & 23.30 & 25.58 & 26.82 & $449^{*}$ & $6.6 \mathrm{E}-61$ \\
\hline Sugar Beet+Maize & 21.72 & 21.83 & 22.51 & $108^{*}$ & $6.7 \mathrm{E}-29$ \\
\hline
\end{tabular}

Note: (*) indicates statistical significant difference at the $5 \%$ level.

Source: The results of the socio-economic farm and household survey 2014/2015. 
$\varepsilon r v \quad$ An Economic Assessment for the Effect of Farm Location along the same Irrigation Canal on Crop Production in Dakahlia Governorate

The results showed statistical significant effect of location on the average total revenues of all crop rotations among the three farm locations. Besides, the results of the mathematical model (equation 1) revealed significant increase of the average total revenues for wheat+rice rotation followed by head and middle farmers respectively estimated at LE 1.76 and 1.55 thousand over that obtained at the tail-end (Table 9). Hence, the effect of the head-reach location on the average total revenue of this crop rotation is greater than that of the middle location. The location explains about $34 \%$ of the variation in the average total revenues of this rotation for farmers in these locations. Likewise, the results revealed significant increase of the average total revenues for clover+rice rotation for head-reach and middle farmers respectively reached LE 3.11 and 2.54 thousand over that obtained at the tail. The variation of location explains $46 \%$ of the variation in the average total revenues of this rotation for farmers in these locations. Conversely, the results showed significant decrease of the average total revenues for sugar beet+cotton rotation for head and middle farms respectively estimated at LE 3.51 and 1.24 thousand below that obtained at the tail. Besides, the variation of location explains $87 \%$ of the variation in the average total revenues of this rotation for farms in these locations. The results showed significant increase of the average total revenues for wheat+maize rotation for head-reach and middle farms respectively reached LE 1.46 and 1.11 thousand over that of tail-enders. The variation of location explains $39 \%$ of the variation in the average total revenues of this rotation for farms in these locations. Similarly, the results revealed significant increase of the average total revenues for clover+maize rotation for head and middle farms respectively reached LE 1.79 and 1.60 thousand over that obtained at the tail. The variation of location explains $27 \%$ of the variation in the average total revenues of this rotation for farmers in these locations. Contrariwise, there is significant decrease of the average total revenues for sugar beet+maize rotation for head and middle farmers respectively reached LE 0.79 and 0.68 thousand below that obtained at the tail. The variation of location explains $61 \%$ of the variation in the average total revenues of this rotation followed by farmers in such locations.

Table (9): The results of the mathematical model for the main crop rotations in the study sample.

\begin{tabular}{|c|c|c|c|c|c|c|c|c|c|}
\hline \multirow{2}{*}{$\begin{array}{c}\text { Average Total } \\
\text { Revenue } \\
\text { (LE/feddan) }\end{array}$} & \multicolumn{3}{|c|}{ Wheat+Rice } & \multicolumn{3}{|c|}{ Clover+Rice } & \multicolumn{3}{|c|}{ Sugar Beet+Cotton } \\
\hline & Coefficient(a) & $\begin{array}{c}\text { T- } \\
\text { statistic }\end{array}$ & P-value & Coefficient(a) & $\begin{array}{c}\mathrm{T}- \\
\text { statistic }\end{array}$ & P-value & Coefficient(a) & T-statistic & P-value \\
\hline Constant & 18516 & $115.84^{*}$ & 1.4E-138 & 29403 & $135.77 *$ & 6E-148 & 26815 & $320.3 *$ & 8E-199 \\
\hline $\mathbf{D}_{\mathrm{h}}$ & 1760 & $7.74 \%$ & 1.98E-12 & 3106 & $10.08 *$ & 3E-18 & -3514 & $-29.50 *$ & 3.3E-61 \\
\hline $\mathbf{D}_{\mathrm{m}}$ & 1551 & $7.36 *$ & $1.5 \mathrm{E}-11$ & 2535 & 8.88* & 3E-15 & -1237 & $-11.21 *$ & 4.2E-21 \\
\hline F-value & \multirow{2}{*}{\multicolumn{3}{|c|}{$\begin{array}{c}37.26 * \\
0.34\end{array}$}} & \multirow{2}{*}{\multicolumn{3}{|c|}{$\begin{array}{c}59.4^{*} \\
0.46\end{array}$}} & \multicolumn{3}{|c|}{$449 *$} \\
\hline Adj. $\mathbf{R}^{2}$ & & & & & & & & 0.87 & \\
\hline & \multicolumn{3}{|c|}{ Wheat+Maize } & \multicolumn{3}{|c|}{ Clover+Maize } & \multicolumn{3}{|c|}{ Sugar Beet+Maize } \\
\hline Constant & 21294 & $187.07 *$ & 6.6E-167 & 32683 & $170.52 \%$ & 2E-161 & 22512 & $538.1 *$ & 1E-229 \\
\hline $\mathbf{D}_{\mathrm{h}}$ & 1463 & $9.03 *$ & 1.39E-15 & 1794 & $6.58 *$ & 9.3E-10 & -794 & $-13.34 *$ & $1.5 \mathrm{E}-26$ \\
\hline $\mathbf{D}_{\mathrm{m}}$ & 1114 & $7.43 *$ & $1.07 E-11$ & 1595 & $6.32 *$ & 3.5E-09 & -680 & $-12.34 *$ & 5.4E-24 \\
\hline F-value & \multirow{2}{*}{\multicolumn{3}{|c|}{$\begin{array}{c}45.55^{*} \\
0.39\end{array}$}} & \multirow{2}{*}{\multicolumn{3}{|c|}{$\begin{array}{c}27.14^{*} \\
0.27\end{array}$}} & \multirow{2}{*}{\multicolumn{3}{|c|}{$108^{*}$}} \\
\hline Adj. $\mathbf{R}^{2}$ & & & & & & & & & \\
\hline
\end{tabular}

Note: $(*)$ indicates statistical significant difference at the $5 \%$ level.

Source: The results of the socio-economic farm and household survey 2014/2015.

\section{Concluding remarks, recommendations and policy implications}

For the sake of testing the hypothesis that head, middle and tail-end farms located along the same canal gain the same yields, same levels of economic efficiency and water use efficiency, the current study aims at analysing the impact of farm location on such variables for a sample of 140 farmers selected from Dakahlia Governorate using a mathematical model by means of dummy variable technique and estimating the production functions for the studied crops. Our findings showed that farm location significantly affected the yields, total revenues and gross margins for 
all of the studied crops whereas, it is found that farm location significantly affected the variable costs, water productivity and gross margins per unit of water for wheat, sugar beet, rice, and cotton grown in the three locations.

The results of the developed mathematical model showed statistical significant effect of farm location on the yields and total revenues of wheat, clover, sugar beet and maize whereas, there was significant effect of farm location on the gross margins of clover, rice and maize.

Our results are supported by another study by (El-Amir et al, 2001) indicating that the yields of major crops grown at the head and in the middle of the canals are significantly higher than those obtained at the tail-ends due to inequality of water distribution along farms on the canal. Head-reach farmers gained the highest average total revenues for wheat and clover crop rotations in the study area whereas, tail-end farmers gained the highest average total revenues for sugar beet crop rotations. The results showed significant effect of location on the average total revenues of all crop rotations among farm locations and the developed mathematical model showed significant effect of farm location on the average total revenues all crop rotations in the study area, as well. Based on these results, it was found that farm location along the same canal affects the crops' yields, economic efficiency, water use efficiency, average total revenues of crop rotations prevailing in the study area.

In order to decrease the farm-level variations in yields and inequities in water distribution along different reaches of the same canal, the current study recommends the need to replace traditional open earthen canals by new improved ones and reallocate water supplies among head and tail-enders using continuous irrigation water flow so that tail-enders can better cope with risks associated with water unavailability. The government is also advised to give due attention to farm location on the same canal for the design of the cropping pattern and to encourage farmers to formulate Water Users' Associations (WUAs). This is expected to pave the way to ensure equal water distribution thus, reduce the conflict over water among farmers in the head, middle and tail-ends. This sheds light on the need for reforming existing WUAs already in place so that the concerns of the tail-enders could be better heard in the decision-making process. Tail-enders are encouraged to promote on-farm agronomic practices targeting saving irrigation water e.g. using short-age and watersaving improved varieties, using raised-bed, using deficit irrigation technique, switching to crops that need less water to boost water use efficiency, carrying out night irrigation ... etc.

Our recommendations are supported not only by our findings but also by the objectives of the Agricultural Sustainable Development Strategy 2030 targeting rationalizing water and land use through improving land and water use, introduction of improved varieties, and improving the livelihood of rural inhabitants (MALR, 2009). Moreover, these recommendations are in perfect concordance with the objectives of the Draft of the Development and Management of Water Resources Strategy 2050 targeted improving on-farm water management practices such as developing canal and water distribution structures, and forming WUAs (MWRI, 2010).

\section{References:}

Allam, M. N., (2002). Survey on Modernization of Irrigation Schemes Case Studies (Working Documents), Case Study from Egypt Survey on Irrigation Modernization: Beni Ebeid Area, Cairo, Egypt.

Allam, M. N. et al, (2005). Irrigation Systems Performance in Egypt, Irrigation systems performance, CIHEAM. p. 85-9 8, Options Méditerranéennes: Série B. Etudes et Researches; n. 52, Bari. 
\& $\sim_{q}$ An Economic Assessment for the Effect of Farm Location along the same Irrigation Canal on Crop Production in Dakahlia Governorate

Bhattarai, M. et al, (2002). Irrigation impacts on income inequality and poverty alleviation: Policy issues and options for improved management of irrigation systems, Working Paper 39. International Water Management Institute, Sri Lanka.

El-Amir, R. M. et al, (2001). An Economic Assessment of Farmers Organizations under Newly Adapted Technologies in both Old and New Lands in Egypt, the proceeding of the 64th Annual Meeting for the Rural Sociological Society, Albuquerque, New Mexico, U.S.A., August 15-19, 2001.

El Gamal, F., (2000). Irrigation in Egypt and Role of National Water Research Center, In: Lamaddalena N. (ed.) Annual Meeting of the Mediterranean Network on Collective Irrigation Systems (CIS_Net), CIHEAM. p. 3344, Options Méditerranéennes: Série B. Etudes et Researches; n. 31, Bari.

FAO, (1989). Irrigation Water Management: Irrigation Scheduling, Training Manual no. 4, Food and Agriculture Organization of the United Nations (FAO), Italy.

FAO, (2005). Towards Integrated Planning of Irrigation and Drainage in Egypt in Support of the Integrated Irrigation Improvement and Management Project (IIIMP), Final Report, Food and Agriculture Organization of the United Nations (FAO), Italy.

FAO, (2012). Crop Yield Response to Water, Irrigation and Drainage Paper 66, Food and Agriculture Organization of the United Nations (FAO), Italy.

HLPE, (2015). Water for food security and nutrition, A report by the High Level Panel of Experts on Food Security and Nutrition of the Committee on World Food Security, Italy.

Hoevenaars, J. and Slootweg, R., (2004). Towards Integrated Planning of Irrigation and Drainage in Egypt-In support of the IIIMP: Rapid Assessment Study Towards Integrated Planning of Irrigation and Drainage in Egypt-Natural Resources Perspective.

Holmen, H., (1991). Building organizations for rural development, State and cooperatives in Egypt, Lund University Press, Sweden.

Malashkhia, N., (2003). Social and Environmental Constraints to the Irrigation Water Conservation Measures in Egypt, Lund University Press, Sweden.

MALR, (2009). Sustainable Agricultural Development Strategy towards 2030 (SADS), Agricultural Research \& Development Council, Ministry of Agriculture and Land Reclamation (MALR), Egypt.

MALR, (2012-2014). Bulletin of Agricultural Statistics. Economic Affairs Sector, Central Department of Agrarian Economics \& Statistics, Ministry of Agriculture \& Land Reclamation (MALR), Egypt.

MWRI, (1998). Egypt's Irrigation Improvement Program, Report No. 7, prepared by IRG/Winrock International and Nile Consultants through UASID funded project on Agricultural Policy Reform Program.

MWRI, (2010). The Draft of the Development and Management of Water Resources Strategy 2050, Ministry of Irrigation and Water Resources (MWRI), Egypt.

Rao, P. S., (1987). Relative Equity Ratio: Concept and Method of Computation, IIMI Duplicated, Sri Lanka. 
Santha, A. et al, (2013). Income inequality among major irrigation schemes in Sri Lanka: Gini decomposition approach. In: Proceedings of the Kuala Lumpur International Business, Economic and Law Conference, April 89, 2013, Kuala Lumpur, Malaysia. Pp. 118-127.

Snedecor, G. W.; Cochran, William G. (1989). Statistical Methods (8th ed.). Ames, Iowa: Blackwell Publishing Professional. ISBN 978-0-8138-1561-9. Retrieved 2011-08-05.

Svendsen, M., (2009). Integrated Water Resource Management II, Performance Monitoring Plan, Report No. 6, Contract No. EPP-I-00-04-00024-00 Task Order No. 06.

WMRI, (2010). Monitoring and Evaluation of Integrated Irrigation Improvement and Management Project, Water Management Research Institute (WMRI), Summer 2009 and Winter 2009/2010), Part 1, Egypt.

\section{التحليل الاقتصادي لأثز موقع المزرعة من الترعة على إنتاج المحاصيل بمحافظة الدقهلية حماد حسني أحمد السيد معه بحوث الاقتصاد الزراعي - مركز البحوث الزراعية}

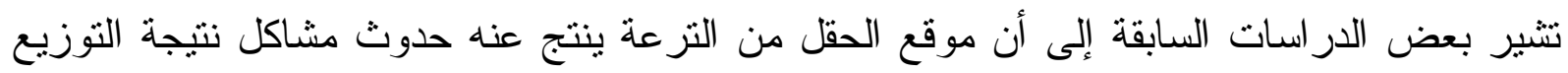

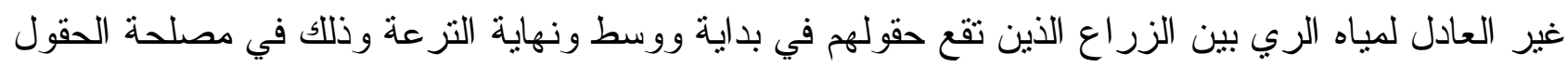
الو اقعة في بداية الترعة، حيث غالباً ما تصل كميات صغيرة من مياه الري إلى لـئ الحقول التي تقع في نهاية

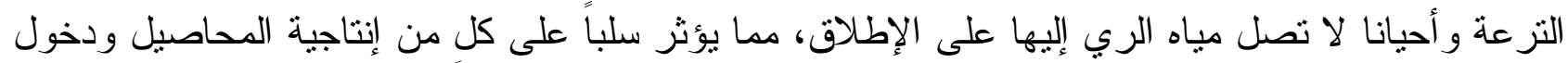

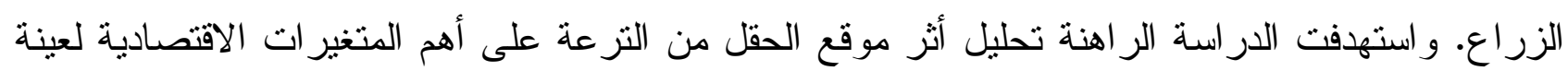

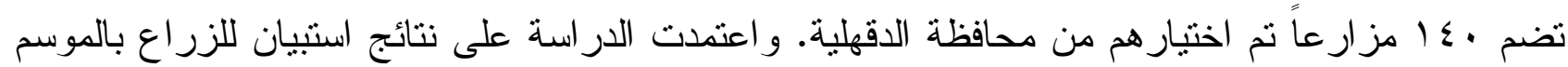

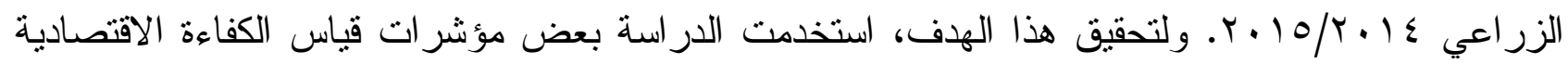

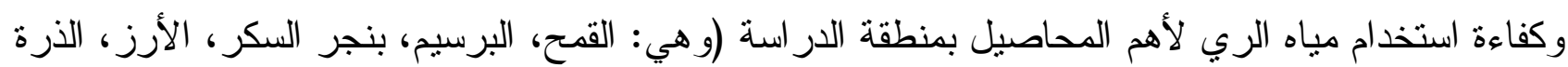

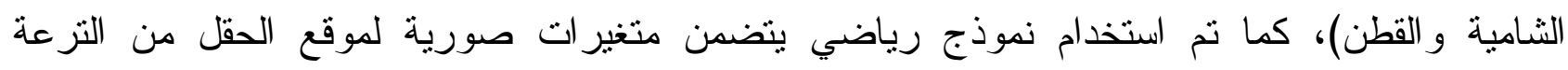

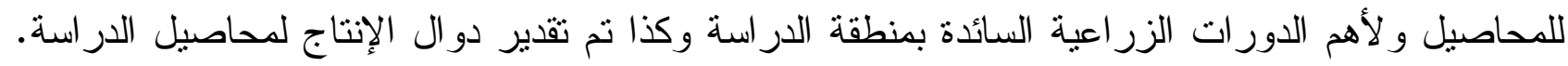

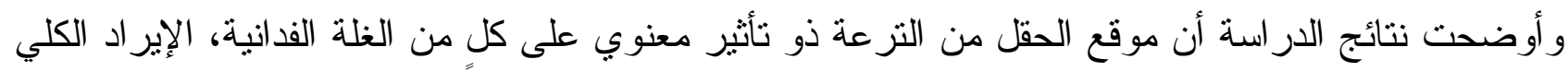

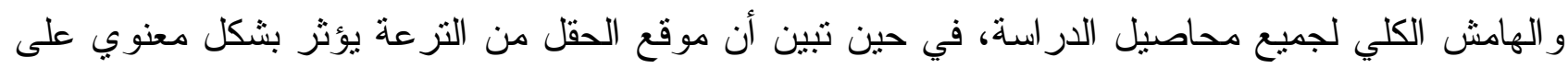

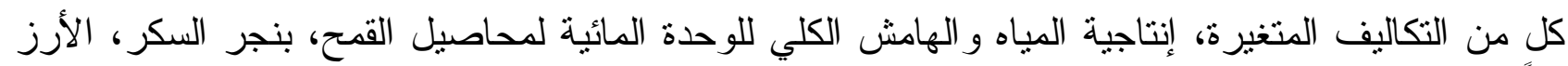

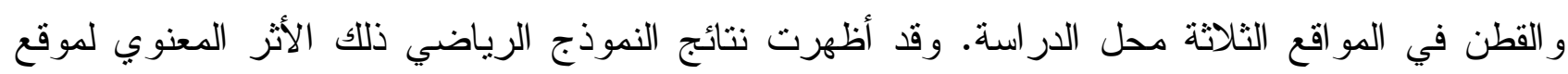

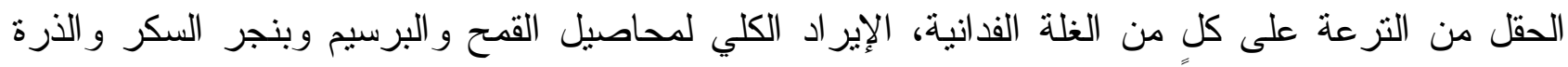
الثامية، في حين تبين أن موقع الحقل من التزعة يؤثر بشكل معنوي على الهامش الكلي لمحاصيل البرسيم

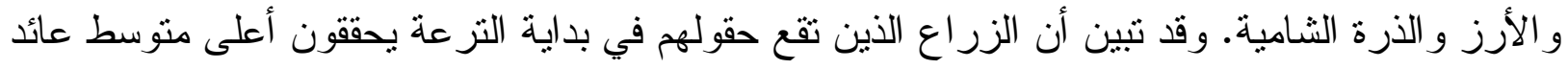



same Irrigation Canal on Crop Production in Dakahlia Governorate

كلي للدور ات الزراعية التي تضم محاصيل القهح والبرسيم، في حين يحقق الزراع الذين ثقع حقولهم في نهاية الترعة أعلى متوسط عائد كلي للدور ات الزر اعية التي تضم محصول بنجر السكر • وقد أظهرت النتائج أن موقع الحقل من التزعة ذو تأثثر معنوي على منتسط عائد كلي لكافة الدورات الزر اعية السائدة بمنطقة الدراسة. وتوصي الدراسة بضرورة أخذ موقع الحقول من التزعة في الاعتبار عند وضع التركيب المحصولي التأثيري ، فضلاً عن تشجيع الزراع على تكوين روابط لمستخدمي المياه و إعطاء الفرصة للزر اع الذين تقع حقولهم في نهاية الترعة للمشاركة الفعالة في عملية اتخاذ القرار فيما يتعلق بمناوبات الري، بالإضافة إلى تشجيع الزراع الذين تقع حقولهم في نهاية التزعة على تنبي الممارسات الزر اعية التي تساعدهم

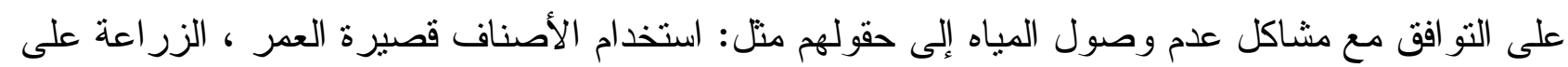
مصاطب عريضة، استخدام تقنية الري الناقص، الري الليل وزر اعة المحاصيل التي تحتاج إلى كميات أقل من مياه الري. 